\title{
Comparison of selective agars recommended by method ISO 11290-1 and chromogenic agars for the isolation of Listeria sp. in refrigerated sausages
}

\author{
Thalyta Marina Benetti ${ }^{1, *}$, Cristina Leise Bastos Monteiro ${ }^{1}$, Márcia Regina Beux ${ }^{1}$, Wanda \\ Moscalewski Abrahão ${ }^{2,3}$
}

\begin{abstract}
${ }^{1}$ Department of Basic Pathology, Federal University of Paraná, ${ }^{2}$ Department of Pharmacy, Federal University of Paraná, ${ }^{3}$ Section of Food Microbiology, Paraná State Central Laboratory
\end{abstract}

\begin{abstract}
The aim of this study was to determine the prevalence of Listeria sp. in refrigerated sausages, and to compare the performance of the selective plating media employed in the ISO 11290-1 method (PALCAM and Oxford agars) with chromogenic agars (Chromogenic Listeria agars CM 1080 (OCLA) and CM 1084). The prevalence of Listeria $\mathrm{sp}$. detected was $52.9 \%$, comprising $13.7 \%$ L. monocytogenes strains. The efficacy of the four agars for the isolation of $L$. monocytogenes proved to be satisfactory. Despite differences in composition of the chromogenic media assessed, these disparities did not affect concordance among results. However, PALCAM agar was shown to suppress other microorganisms more effectively, being more applicable for detecting Listeria strains present in lower quantities. Based on these results, the use of PALCAM agar, in combination with a chromogenic media, is recommended for enhanced isolation of atypical Listeria sp. strains in meat products.
\end{abstract}

Uniterms: Listeria sp./detection/meat products. Meat products/qualitative analysis. Refrigerated sausages/ qualitative analysis. PALCAM Agar. Oxford Agar. Chromogenic Agar.

Este estudo teve como objetivo a análise da prevalência de Listeria sp. em linguiças resfriadas e a comparação dos meios seletivos utilizados no plaqueamento do método ISO 11290-1 (Ágar PALCAM e Ágar Oxford), e ágares cromogênicos (Ágares Listeria Cromogênico CM 1080 (OCLA) e CM 1084 (ISO)). A frequência de Listeria sp. foi de 52,9\%, sendo que destas, 13,7\% corresponderam à $L$. monocytogenes. A eficácia dos quatro ágares para o isolamento de L. monocytogenes demonstrou-se satisfatória. Apesar de haver algumas diferenças nas composições dos meios cromogênicos analisados, estas não pareceram influenciar nas concordâncias entre os resultados expressos. Contudo, o ágar PALCAM mostrou-se mais eficaz na supressão de outros micro-organismos, aumentando, assim, a possibilidade de detecção de espécies de Listeria presentes em número reduzido. Através deste trabalho sugere-se a utilização do ágar PALCAM associado a um meio cromogênico para aumentar a chance de isolamento de cepas atípicas de Listeria sp. em produtos cárneos.

Unitermos: Listeria sp./detecção/produtos cárneos. Produtos cárneos/análise qualitativa. Lingüiças resfriadas/análise qualitativa. Ágar PALCAM. Ágar Oxford. Ágar cromogênico.

\section{INTRODUCTION}

The scientific community was first alerted to the dangers of listeriosis during the 1980 s following a series of outbreaks in North America and Europe. In 1988, the

*Correspondence: T. M. Benetti. Departamento de Patologia Básica, Setor de Ciências Biológicas, Universidade Federal do Paraná. Rua Martim Afonso, 3074, ap.208 - Bairro Bigorrilho, 80730-030 - Curitiba - PR, Brasil. E-mail: thaly_benetti@hotmail.com
World Health Organization (WHO) established that the consumption of contaminated foodstuffs was the primary route of transmission of L. monocytogenes in humans (Faber, Peterkin, 1991; Oliveira, 1993).

Listeria sp. is found widely in nature, explaining the frequency of its emergence in foods, from production to end-consumption (Beuchat, 1996).

Research into L. monocytogenes in ready-to-eat foods has become increasingly important, particularly 
given that the food products involved in the outbreaks and sporadic cases of listeriosis were predominantly industrially processed refrigerated foods with a long shelf life.

As Listeria has specific nutritional requirements, the cultivation stage involving enrichment broths plays a key role in the recovery and multiplication of viable cells from the microorganisms present in the sample. However, in the stages following the enrichment, selective media can hamper microorganism recovery due to sensitivity to the antibiotics in the media, resulting in their suppression by these inhibitory agents (Trabulsi, Althertum, 2008).

Two different selective agars, PALCAM and Oxford, recommended by the International Organization for Standardization (ISO) (1996) have been adopted in protocols for the detection/enumeration of $L$. monocytogenes. These methods incorporate added esculin which forms greyish-green to black colonies, sometimes evidenced by blackening of the media, aiding visualization and identification of colonies. However, this traditional method is unable to differentiate L. monocytogenes colonies form other Listeria sp. species. Consequently, the detection of $L$. monocytogenes requires additional identification procedures entailing pain-staking tests, which are both time-consuming and costly.

However, researchers have sought to improve selectivity by proposing modifications in the formulas used. Hemolytic ceftazidime lithium chloride agar - HCLA, "enhanced haemolysis agar" - EHA and modified forms, Listeria monocytogenes blood agar - LMBA, Rapid'L Mono developed by L' Mono de Foret, Dorey (1997), and Chromogenic Listeria agar Base (Oxoid chromogenic Listeria agar) (OCLA) CM 1080 and (ISO) CM 1084, both supplied by Oxoid (Ottaviani et al.,1997), are examples of media able to differentiate Listeria monocytogenes from Listeria sp. (Vlaemynck et al., 2000).

The aim of the present study was to analyse the prevalence of Listeria sp. in refrigerated sausages produced in Paraná State, Brazil, and to compare the performance of selective plating media employed in the ISO 11290-1 method (PALCAM and Oxford agars) with chromogenic agars (Chromogenic Listeria agars CM 1080 (OCLA) and CM 1084) in terms of efficacy for the detection of Listeria $\mathrm{sp}$. in naturally contaminated samples.

\section{MATERIAL AND METHODS}

\section{Selection of samples}

A total of 51 samples of pre-packed refrigerated sausages, purchased from different commercial outlets in the State of Paraná and produced in the South of Bra- zil, were collected. The minimum amount of $250 \mathrm{~g}$ was acquired for each sample to ensure representativity as recommended by the RDC (Board of Commerce Resolution) 12 of $02 / 01 / 2001$ published by ANVISA (National Health Surveillance Agency) (Brazil, 2001).

\section{Methods}

The conventional culture method was performed as per ISO 11290-1 recommendations. However, in the present study, for the third step of the ISO 11290-1 for the identification of Listeria sp. involving the process of isolating the bacterium, an assessment using four commercially available agars was performed, namely: PALCAM agar supplemented with SR 0150E (polymyxin B $5 \mathrm{mg}$, acriflavine $\mathrm{HCl} 2.5 \mathrm{mg}$ ) (Oxoid, England); Oxford agar selective for Listeria supplemented with Listeria Selective Supplement (Oxford Formulation) SR0140E (cycloheximide $200 \mathrm{mg}$, colistin sulphate $10 \mathrm{mg}$, acriflavine $2.5 \mathrm{mg}$, cefotetan 1mg, phosphomycin $5 \mathrm{mg}$ ) (Oxoid, England); Chromogenic Listeria agar CM 1080 (OCLA) (Oxoid, England) supplemented with Chromogenic Listeria Selective Supplement SR 0227E (nalidixic Acid 13 mg, polymyxin B 38,350 IU, amphotericin $5 \mathrm{mg}$, ceftazidime $3 \mathrm{mg}$ ) (Oxoid, England) and Chromogenic Listeria Differential Supplement SR 0228E (lecithin solution $20 \mathrm{~mL}$ ); Chromogenic Listeria Agar CM 1084 (Oxoid, England) supplemented with Chromogenic Listeria Differential Supplement SR 0228E and Chromogenic Listeria Selective Supplement (ISO) SR 0226E (nalidixic Acid $10.0 \mathrm{mg}$, polymyxin B 38,350 IU, amphotericin $5 \mathrm{mg}$, ceftazidime $10 \mathrm{mg}$ ) (Oxoid, England). Agar plates were incubated at $37^{\circ} \mathrm{C}$ for 48 hours.

From 3 to 5 colonies per plate containing typical colonies were selected for subsequent confirmation.

Typical colonies were streaked onto tubes containing Tryptic Soy agar supplemented with $0.6 \%$ yeast extract (TSA-YE) (Laborclin, Brazil) and incubated at $30{ }^{\circ} \mathrm{C}$ for 24 and 48 hours.

Typical colonies were confirmed by motility tests performed through inoculation of enriched broth in tubes of sulfide-indole motility with the addition of $0.05 \%$ triphenyltetrazolium chloride (modified SIM) (Laborclin, Brazil) and incubation at $25^{\circ} \mathrm{C}$ for up to 7 days under daily observation. In parallel, strains were identified using the API ${ }^{\circledR}$ Listeria system (Biomerieux, France).

Results for the four agars analyzed were grouped by characteristics. Comparative analysis was carried out based on two groups: Chromogenic agars (CM 1080 and CM 1084) and Classic agars (PALCAM and Oxford). Analysis of concordance between positive and negative 
results was carried out by comparing the ISO method for classic versus chromogenic agars for the detection of Listeria $\mathrm{sp}$. in refrigerated sausages according to the model proposed by Jekel et al. (1999).

\section{RESULTS AND DISCUSSION}

Based on results of the 51 samples analyzed using the selective media employed in the present study, the prevalence of Listeria sp. detected in refrigerated sausages was $52.9 \%$, comprising $13.7 \%$ L. monocytogenes. L. grayi was found in $19.7 \%$ of the samples studied whereas $L$. innocua and L. welshimeri were identified in $13.7 \%$ and $5.9 \%$ of cases, respectively. The above results agreed with those of samples confirmed by the API ${ }^{\circledR}$ Listeria system.

Separate assessment of the selective media revealed $52.9 \%$ positivity for PALCAM agar ( $\mathrm{n}=27), 47.0 \%$ for Oxford agar ( $\mathrm{n}=24), 43.1 \%$ for Chromogenic Listeria agar CM $1080(\mathrm{n}=22)$, and $45.1 \%$ for Chromogenic Listeria agar CM $1084(n=23)$.

Congruent with the final result, PALCAM agar showed no false-negatives, whereas Oxford agar, Chromogenic Listeria CM 1084 and CM 1080 agars had 3, 4 and 5 false-negatives, respectively.

These results confirm that election of a single selective media other than PALCAM agar would lead to approval of false-negative samples (contaminated but undetected in analysis) for consumption, posing a potential health risk since infected food batches may be cleared due to non-detection of the pathogen.

Comparison of the results for chromogenic media (Table I) show positive concordance of 32 samples $(62.7 \%)$ and negative concordance in 18 samples (35.3\%), giving an overall agreement of $98.0 \%$ (Table II).

TABLE I - Positive and negative results comparing chromogenic agars for detection of Listeria sp. in refrigerated sausages

\begin{tabular}{lc}
\hline & CM1080 Vs. CM1084 \\
\hline Positive agreement & 32 \\
Positive disagreement & 1 \\
Negative disagreement & 0 \\
Negative agreement & 18 \\
\hline Total & 51 \\
\hline
\end{tabular}

Positive disagreement was disclosed in only one sample $(2.0 \%)$, while no negative disagreement was found.

The kappa test was used to compare chromogenic agars, yielding $96.0 \%$ agreement, representing excellent concordance among results obtained for the agars ana-
TABLE II - Concordance between positive and negative results comparing chromogenic agars for detection of Listeria sp. in refrigerated sausages

\begin{tabular}{lc}
\hline Degree of concordance & CM1080 Vs. CM1084 \\
\hline Overall percentage agreement & $98.0 \%$ \\
Kappa & $96.0 \%$ \\
\hline
\end{tabular}

lysed, i.e. there was strong agreement among correlations assessed.

Despite some differences in composition of the chromogenic media analyzed, these appeared to have no influence on concordance among the results.

Comparison of the results for classic media (Table III) revealed positive agreement for 34 samples (66.5\%) and negative agreement in 18 samples $(23.5 \%)$, giving an overall agreement of $90.0 \%$ (Table IV). These findings indicate a greater capacity of PALCAM agar for identifying lower concentrations of Listeria sp. compared with Oxford agar.

TABLE III - Positive and negative results comparing classic agars for detection of Listeria sp. in refrigerated sausages

\begin{tabular}{lc}
\hline & PALCAM Vs. OXFORD \\
\hline Positive agreement & 34 \\
Positive disagreement & 4 \\
Negative disagreement & 1 \\
Negative agreement & 12 \\
\hline Total & 51 \\
\hline
\end{tabular}

TABLE IV - Concordance between positive and negative results comparing classic agars for detection of Listeria sp. in refrigerated sausages

\begin{tabular}{lc}
\hline Degree of concordance & PALCAM Vs. OXFORD \\
\hline Overall percentage agreement & $90.0 \%$ \\
Kappa & $76.0 \%$ \\
\hline
\end{tabular}

Positive disagreement was disclosed in 4 samples (7.8\%), while negative disagreement was found in only one sample $(2.0 \%)$.

The kappa test was used to compare classic agars, yielding $76.0 \%$ agreement, representing excellent concordance among results for the Agars analyzed.

The efficacy of the four Agars for the isolation of L. monocytogenes in the naturally contaminated samples proved satisfactory. However, PALCAM agar was shown to be more effective in isolating all the strains identified 
in the present study, proving capable of detecting Listeria strains present in low concentrations.

Other studies have reported similar efficacy of PALCAM agar in suppressing accompanying microorganisms coupled with higher rates of isolation of Listeria sp. For instance, the study by Gunasinghe et al. (1994), comparing the performance of selective Oxford (Oxoid) and PALCAM (Merck) agars in varieties of Frankfurter sausages, salami and pate, found PALCAM agar to be superior and also noted more effective isolation of Listeria. Nayak et al. (2010), in studies of buffalo meat, noticed that PALCAM agar identified $100 \%$ of species analyzed and was in concordance with results on polymerase chain reaction (PCR). By contrast, Oxford agar showed a recovery rate of $60 \%$. Capita (2001), examining cuts of raw poultry meat, found a significantly higher percentage of tested samples positive for Listeria sp. using PALCAM plating media compared with Oxford agar $(95.0 \%$ versus $87.0 \%)$, respectively. Similarly, a higher percentage of samples was found to be contaminated with $L$. monocytogenes using PALCAM agar $(31.0 \%)$ than with Oxford agar $(27.0 \%)$. In a comparative assessment of different selective isolation media for the detection of Listeria sp., Art and Andre (1991) found that the PALCAM media offered excellent performance, superior to that of Oxford media, and urged for replacement of the latter by another media capable of differentiating $L$. monocytogenes from other Listerias strains.

However, some authors failed to confirm more favorable results using PALCAM agar. Pinto et al. (2001) for example, in a comparative assessment of food and environmental samples, found higher sensitivity for the recovery of L. monocytogenes using Listeria monocytogenes Blood agar (LMBA) compared with both PALCAM and Oxford agars. These authors were unable to distinguish any difference in results using the selective media recommended by the ISO. Becker et al. (2006) performed a comparison of the two selective chromogenic media, ALOA and RAPID'L Mono, with the official plating method recommended by ISO 11290-1, using different food samples. The group noted no significant performance difference among the media studied. Leclercq (2004), examining the performance of the selective PALCAM, Oxford, Rapid'L Mono and ALOA solid media found low recovery and enumeration capabilities, although confirmed ALOA agar as the best isolation media. Rodrigues et al. (2003) obtained superior results using hemolytic ceftazidime lithium chloride agar compared with both PALCAM and Lithium chloride phenylethanol moxalactam media.

PALCAM agar is known for its high selectivity and sensitivity, rendering it useful for the detection of Listeria sp. in products with high bacterial loads such as fresh sausages (Warburton et al., 1992). The selectivity of this media is achieved through the presence of lithium chloride, polymyxin B sulfate, acriflavine $\mathrm{HCl}$ and ceftazidime, which suppress growth of most non-Listeria species present in food (Gunasinghe et al., 1994).

Chromogenic media, such as those described in this study, together with their modified forms, are gradually gaining acceptance by the regulatory authorities (Reissbrodt, 2004; Gasanov et al., 2005). However, despite offering numerous advantages over other tests, such as low cost, ease of interpretation, and shorter execution times, according to the results attained, the performance of the chromogenic media, although satisfactory, remained analytically inferior to the gold standard. Nevertheless, the use of more than one isolation media, employing different selective agents and systems of identifying colonies, is important to increase the chance of isolating the target organism. This procedure is recommended for detecting bacteria whose presence in foods, even at low amounts, can expose consumers to serious risk, as is the case for L. monocytogenes (Rodrigues et al., 2003). Based on the findings of the present study, the use of a combination of different media, such as special alternative media (chromogenic agars) and media containing esculin (PALCAM agar) is recommended. These media are particularly applicable for the detection or enumeration of atypical strains of L. monocytogenes.

\section{ACKNOWLEDGEMENTS}

We would like to thank the Ministry of Health of Paraná and the Central Laboratory of the State of Paraná, particularly for the use of their facilities and provision of funding for the performance of the assays.

\section{REFERENCES}

ART, D.; ANDRE, P. Comparison of three selective isolation media for the detection of Listeria monocytogenes in foods. Zentralbl. Bakteriol., v.275, n.1, p.79-84, 1991.

BECKER, B.; SCHULER, S.; LOHNEIS, M.; SABROWSKI, A.; CURTIS, G.D.W.; HOLZAPFEL, W.H. Comparison of two chromogenic media for the detection of Listeria monocytogenes with the plating media recommended by EN/DIN 11290-1. Int. J. Food Microbiol., v.109, n.1/2, p.127-131, 2006.

BEUCHAT, L.R. Listeria monocytogenes: incidence on vegetables. Food Control, v.7, n.4/5, p.223-228, 1996. 
BRAZIL. National Agency for Sanitary Vigilance. RDC Resolution No. 12, dated January 2, 2001. Technical Regulation on microbiological standards for foods. ANVISA - National Agency for Sanitary Vigilance. DOU., Section I, p.45-53, 2001.

CAPITA, R.; ALONSO-CALLEJA, C.; PRIETO, M.; GARCIA FERNANDEZ, M.C.; MORENO, B. Comparison of PALCAM and modified Oxford plating media for isolation of Listeria species in poultry meat following UVM II or Fraser secondary enrichment broths. Food Microbiol., v.18, n.5, p.555-563, 2001.

FARBER, M.; PETERKIN, P.I. Listeria monocytogenes, a foodborne pathogen. Microbiol. Rev., v.55, n.3, p.476-511, 1991.

GASANOV, U.; HUGHES, D.; HANSBRO, P.M. Methods for the isolation and identification of Listeria spp. and Listeria monocytogenes: a review. FEMS Microbiol. Rev., v.29, n.5, p.851-875, 2005.

GUNASINGHE, C.P.G.L.; HENDERSON, C.; RUTTER, M.A. Comparative study of two plating media (PALCAM and Oxford) for detection of Listeria species in a range of meat products following a variety of enrichment procedures. Lett. Appl. Microbiol., v.18, n.3, p.156-158, 1994.

I N T E R N AT I O N A L O R G A N I Z A T I O N F O R STANDARDIZATION (ISO) (1996). Microbiology of food and animal feeding stuffs - Horizontal method for the detection and enumeration of Listeria monocytogenes - Part 1: Detection method, International Standard ISO 11290-1: 1996, Geneva,Switzerland. Available at: <http://www.iso. org/iso/em/CataloqueListPage.CataloqueList?ICS1=07\&I CS2 $=100 \&>$. Accessed on: 30 Apr. 2008.

JEKEL, J.F.; ELMORE, J.G.; KATZ, D.L. Epidemiology, biostatistics and preventive medicine. Porto Alegre: Artmed, 1999. $328 \mathrm{p}$.

LECLERCQ, A. Atypical colonial morphology and low recoveries of Listeria monocytogenes strains on Oxford, PALCAM, Rapid'L.mono and ALOA solid media. $J$. Microbiol. Meth., v.54, n.2, p.251-258, 2004.

L'MONO DE FORET, Q.C.; DOREY, J.F. Rapid and effective method for preparation of fecal specimens for PCR assays. J. Clin. Microbiol., v.35, n.1, p.281-283, 1997.
NAYAK, J.B.; BRAHMBHATT, M.N.; SAVLIA, C.V.; BHONG, C.D; ROY, A.; KALYANI, I.H.; PARMAR, B.C. Detection and characterization of Listeria species from buffalo meat. Buffalo Bull., v.29, n.2, p.83-87, 2010.

OLIVEIRA, A.N. Bacteria of the genus Listeria in milk and dairy products in retail trade in Goiania - Belo Horizonte, Goiás, Brazil, 1993. 101f. [Dissertation of Master degree of Veterinary Medicine. Veterinary School. University of Minas Gerais].

OTTAVIANI, F.; OTTAVIANI, M.; AGOSTI, M. Differential Agar medium for Listeria monocytogenes. "Quimper Froid Symposium proceedings" P6 A.D.R.L.A. Quimper (F), p.16-18, 1997.

PINTO, M.; BURRI, S.; MENA, C.; ALMEIDA, G.; CARNEIRO, L.; TEIXEIRA, P.; GIBBS, P.A. Comparison of Oxford Agar, PALCAM and Listeria monocytogenes Blood Agar for the recovery of L. monocytogenes from foods and environmental samples. Food Control, v.12, n.8, p.511-514, 2001.

REISSBRODT, R. New chromogenic plating media for detection and enumeration of pathogenic Listeria spp. - an overview. Int. J. Food Microbiol., v.95, n.1, p.1-9, 2004.

RODRIGUES, D.A.; FRANCO, B.D.G.M.; LANDGRAF, M.; DESTRO, M.T. Avaliação da eficiência de três agares seletivos no isolamento de Listeria monocytogenes. Cienc. Tecnol. Aliment., v.23, supl., p.87-92, 2003.

TRABULSI, R.L.; ALTERTHUM, F. Microbiology. 5.ed. São Paulo: Atheneu, 2008. 780 p.

VLAEMYNCK, G.; LAFARGE, V.; SCOTTER, S. Improvement of the detection of Listeria monocytogenes by the application of Aloa, a diagnostic, chromogenic isolation medium. J. Appl. Microbiol., v.88, p.430-441, 2000.

WARBURTON, D.W.; FARBER, J.M.; POWELL, C.; TIWARI, N.P.; READ, S.; PLANTE, R.; BABIUK, T.; LAFFEY, P.; JAURI, T.; MAYERS, P., CHAMPAGNE, M.J.; HUNT, T.; LACASSE, P.; VIET, K.; SMANDO, R.; COATES, F. Comparison of methods for optimum detection of stresses and low levels of Listeria monocytogenes. Food Microbiol., v.9, n.2, p.127-145, 1992.

Received for publication on $19^{\text {th }}$ April 2012 Accepted for publication on $21^{\text {st }}$ August 2012 